原 著

\title{
超音波パルスの人体モデル内における伝搬・集束過程の数値シミュレーションと観測
}

\author{
中村修・森 田長吉・岡 崎 \\ 千葉工業大学 \\ 㧣東芝，医用機器技術研究所* \\ （論文受理 1994年 5 月 6 日） \\ （最終論文受理１994年 9 月16日）
}

清*

(Code No. 762)

Key words: Ultrasonic pulse, Lithotripter, Medical ultrasonic wave, Propagation, Numerical analysis

\section{NUMERICAL SIMULATION AND EXPERIMENT OF PROPAGATION AND FOCUSSING PROCESS OF ULTRASONIC PULSES IN BIOLOGICAL TISSUES}

\author{
Osamu Nakamura, Nagayoshi Morita, Kiyoshi OKaZ̆aki* \\ Chiba Institute of Technology \\ Medical Engineering Laboratory, TOSHIBA Corporation*
}

\section{Summary}

As a basic study on the echo trigger pulse propagation in the human body in relation to the Extracorporeal Shock Wave Lithotripter, an investigation on the problems of propagation and convergence of ultrasonic pulses ejected from arc-shaped piezoceramic transducers into the human body model was carried out, together with a comparative study of the results of a computer simulation with those of the experiment. The numerical analysis was performed using a newly-devised method similar to the so-called FE-TD method widely used for analyzing electromagnetic fields.

\section{1.はじめに}

強力な超音波パルスを生体内に照射すると，生体媒質の非線形 効果 ${ }^{1)}$ も作用して衝撃波が生じる。この衝撃波を結石破砕治療に 利用した装置の一つが圧電型の体外衝撃波結石破砕装置 (Extracorporeal Shock Wave Lithotripter；ESWL) である²). ESWL を角いる治療法は外科手術なしに治療できるので尿路結 石に対する新しい治療法として定着している。しかし，腎等の呼 吸性移動は予想以上に大きく，この動きを考慮せずに一度の結石 照準で衝撃波を照射し続けると，その過半数は結石を外れて軟部 組織に照射され，結石破砕効果が減少するとともに軟部組織の障 害の可能性が増してくる ${ }^{3)}$. そこでこのミスショット防止法の一 つとしてエコートリガ照射機構が開発されている ${ }^{4-6)}$. エコートリ ガ機構は，圧電型の振動子よりあらかじめ弱い超音波パルスを発 射し，振動子に返ってきた反射波のうち結石の位置からのものを 選別収集し，その包絡線の最大值がある闘値を越えたとき強い衝
撃波を発射するという原理で動作するようになっている．本稿で は，このエコートリガパルスの弱い超音波パルスを人体モデル内 に発射した場合についてその伝搬の様子を検討するために，環状 球面上に配置した振動子から人体モデル内に超音波パルスを発射 させた場合を取り上げ，このパルスの伝搬状況及び焦点への集束 状況を実験で観測するとともに，この結果を数值シミュレーショ ン結果と比較検討する. 数値シミュレーションでは電磁界解析の 分野で最近さかんに用いられている有限差分時間領域法 (FiniteDifference Time-Domain Method) ${ }^{7,8)}$ の基本的な考え方を超音 波の基本式の解析に応用した新しい方法を用いる ${ }^{9,10)}$. また，損失 がある場合にはパルスの減衰がどのように起こるかも調べる.

\section{2. 理 論}

\section{1 基本関係式および解析法}

音波の挙動を支配する基本方程式は次式で表せる。 


$$
\begin{aligned}
& -\Gamma \mathrm{P}=\rho\left(\frac{\partial \mathrm{V}}{\partial \mathrm{t}}\right) \\
& -\frac{\partial \mathrm{P}}{\partial \mathrm{t}}=\mathrm{K} \Gamma \cdot \mathrm{V} \\
& \mathrm{V}=\frac{\partial \Xi}{\partial \mathrm{t}} \\
& \mathrm{P}=-\mathrm{K} \Gamma \cdot \Xi \\
& \text { だし, } \\
& \mathrm{K}=\rho \mathrm{C}^{2}
\end{aligned}
$$

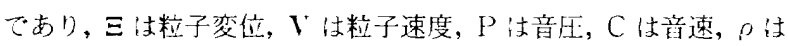
媒質の密度である。

本文で汶超音波バルスの生体内伝搬の基本特性を調べるのが目 的であるので，計算が複雑になる 3 次元りかわりに簡単に計算で きる2次元の問題を取り上げる。この場合

$$
V=i_{x} V_{x}-i_{y} V \text {, }
$$

上なる。ただし，ix，i，吱 $x$ 方向，y方向の単位べタトルである。

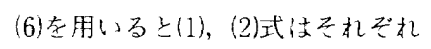

$$
\begin{aligned}
& -\mathbf{i}_{x}\left(\frac{\partial \mathrm{P}}{\partial x}\right)-\mathbf{i}_{y}\left(\frac{\partial \mathrm{P}}{\partial y}\right)=\rho\left\{\frac{\partial}{\partial \mathrm{t}}\left(\mathbf{i}_{x} \bigvee_{x}+\mathbf{i}_{y} V_{y}\right)\right\} \\
& -\frac{\partial \mathrm{P}}{\partial \mathrm{t}}=\mathrm{K}\left(\frac{\partial \mathrm{V}_{x}}{\partial x}+\frac{\partial V_{y}}{\partial y}\right)
\end{aligned}
$$

となる。(7)式から次の2 式在得る。

$$
\begin{aligned}
& -\frac{\partial \mathrm{P}}{\partial x}=\rho\left(\frac{\partial \bigvee_{x}}{\partial \mathrm{t}}\right) \\
& -\frac{\partial \mathrm{P}}{\partial y}=\rho\left(\frac{\partial \bigvee y}{\partial \mathrm{t}}\right)
\end{aligned}
$$

Fig. 1の上うにP, Vx, Vy 在ox，oy間隔の上び々びの位置に 配置し, $\mathrm{n}$ 离離散化した時間ステッブ数とした時, $\mathrm{P}$ を $\mathrm{t}=\mathrm{n} \partial \hat{t}(\mathrm{n}$ $=0,1,2, \cdots)$ という時刻で，また $V_{x}, V_{y}$ 老 $\mathrm{t}=\left(\mathrm{n}+\frac{1}{2}\right)$ ot $(\mathrm{n}$ $=0 ， 1 ， 2 ， \cdots)$ 上いう時刻て観測するもの上する。（8，（9)，(100) 3 式在差分化した式考形し, $P^{n-1}, V^{n-\frac{3}{2}}, V^{n+\frac{3}{2}}$ 考計算していく 式は次のようになる。

$$
P^{n-1}(i, 1)=P^{n}(i, 1)-\frac{K(i, 1) \partial t}{\partial x}\left\{V_{x}^{n-\frac{1}{2}}\left(i-\frac{1}{2}, 1\right)-Y_{x}^{n-\frac{1}{2}}(i\right.
$$

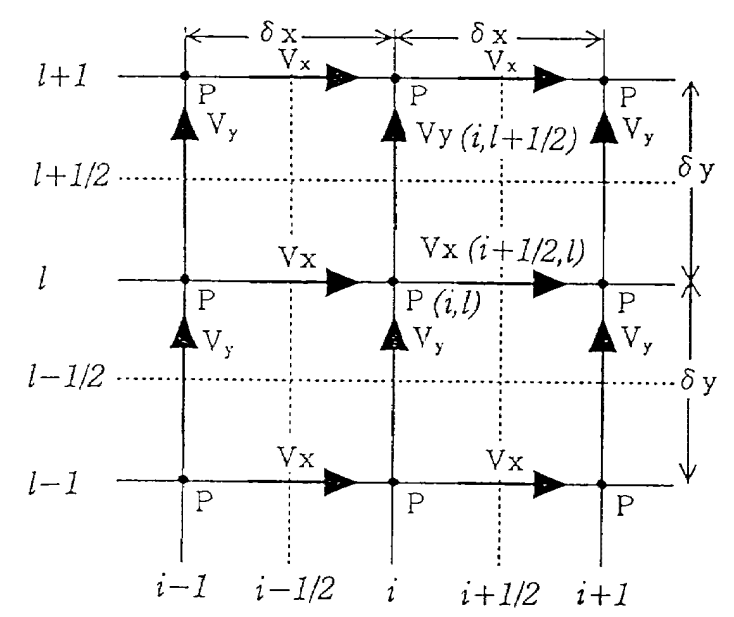

Fig. 1 Lattice division and positions of unknown quan. tities.

$$
\begin{aligned}
& \left.\left.-\frac{1}{2}, 1\right)\right\}-\frac{K(i, 1) \partial t}{\partial y}\left\{Y_{y}^{n-\frac{1}{2}}\left(i, 1+\frac{1}{2}\right)-V_{y}^{n-\frac{1}{2}}\left(i, 1-\frac{1}{2}\right)\right\} \\
& V_{x}^{n-\frac{3}{2}}\left(i-\frac{1}{2}, 1\right)=V^{n} x^{n-\frac{1}{2}}\left(i-\frac{1}{2}, 1\right)-\frac{\partial t}{\rho\left(i-\frac{1}{2}, 1\right) \partial x}\left\{P^{n+i}(i-1,\right.
\end{aligned}
$$$$
\text { 1) } \left.-\mathrm{P}^{n+1}(\mathrm{i}, 1)\right\}
$$

$$
V v^{n-\frac{3}{2}}\left(i+\frac{1}{2}, 1\right)=V_{y}^{n-\frac{1}{2}}\left(i+\frac{1}{2}, 1\right)-\frac{\partial t}{\rho\left(i-\frac{1}{2}, 1\right) \partial y^{\prime}}-\left\{P^{n-1}(i+1,\right.
$$

1) $\left.-\mathrm{P}^{n-1}(\mathrm{i}, 1)\right\}$

なお，本稿の計算例の上うに音圧分布がある有限の領域内でのみ 有限梿になる場合には，計算領域の境界における条件は $\mathrm{P}=0$ で 十分である。この計算にはキャノン・六ストのワークステーシ ヨン，言語はフォートランを用いている。

\section{2 解析モテル}

Fig. 2 に示寺卡な焦点 $\mathrm{S}$ 含志四角形領域 $\mathrm{ABCD}$ を領域 1 とすると，二の領域内が数值計算領域であり，且つ人体に相当す る領域である。A A'B B'領域 2とすると, この領域は水が充 填さ礼る領域上なる。実際のESWLの装置ではここにウオータ バッグを挿入することによって振動子から生体に至る経路の音響 インピーダンスの整合性を高め, 超音波の反射, 屈折等を隇少き せる方法を講じている，従って数値計算ては領域 2 を計算領域か。

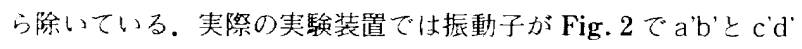
で示される環状球面上に配置されているが, 数值計算では超音波 ハルスの発射位置を領域 $10 \mathrm{AB}$ 上の ab間とcd間だけに設定 古る。

\section{3 計算における超音波パルスの动振法}

数㑲計算で Fig. 2 の y 軸上の ab及びcd間で超音波バルスの 時間変化を与之るに際し， $x=0$ 上（ $y$ 軸上）では $\mathrm{Q}_{\mathrm{L}} \mathrm{Q}_{\mathrm{y}}$ の長さを 超省波が伝搬する時間に相当する漣机が生じるのを考慮する。い ま，振動子上の励振関数として次式

$$
\begin{aligned}
F(t) & =-\frac{1}{2}\left\{1-\cos \left(\frac{\omega t}{t}\right)\right\} \sin \omega t, 0 \leqq t \leqq 4 T \\
& =0, \mathrm{t}<0 \text { or } \mathrm{t}>4 \mathrm{~T}
\end{aligned}
$$

で表されるような $\mathrm{F}(\mathrm{t})$ を考える． $\mathrm{F}(\mathrm{t})$ の)形はFig. 3 のようにな る.この励振関数を睘状球面の振動子上で直接勋振するかわりり，

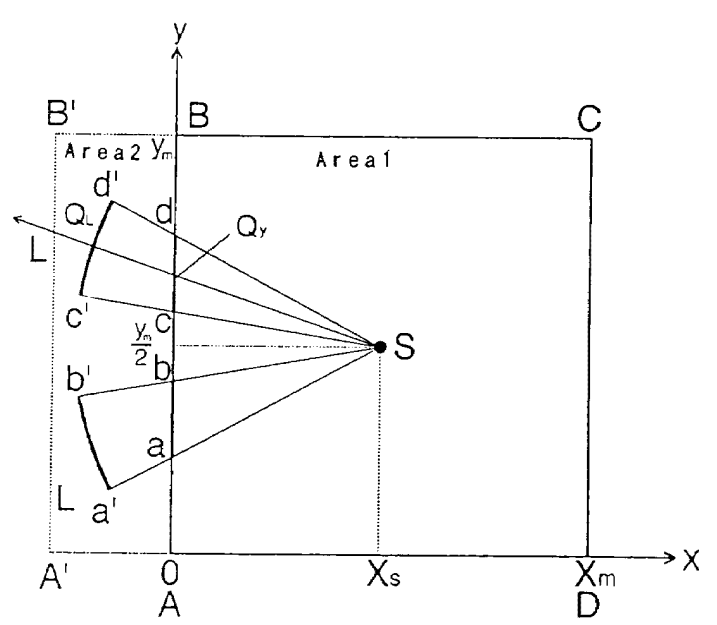

Fig. 2 Model of analysis and part of the excitation. 


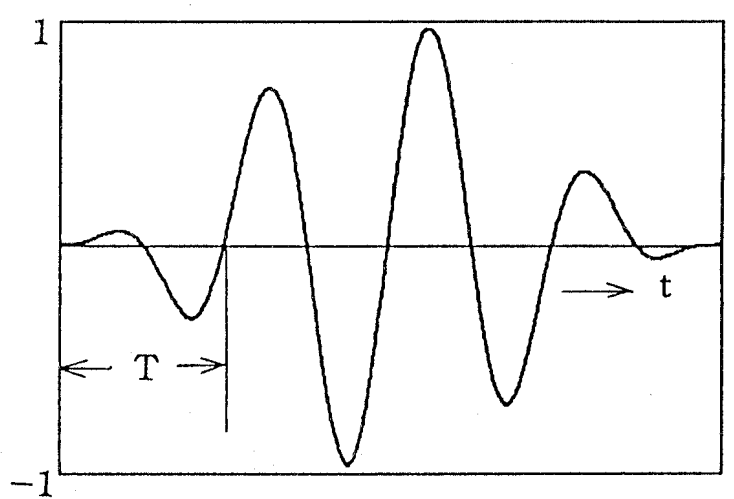

Fig. 3 Excitation function.

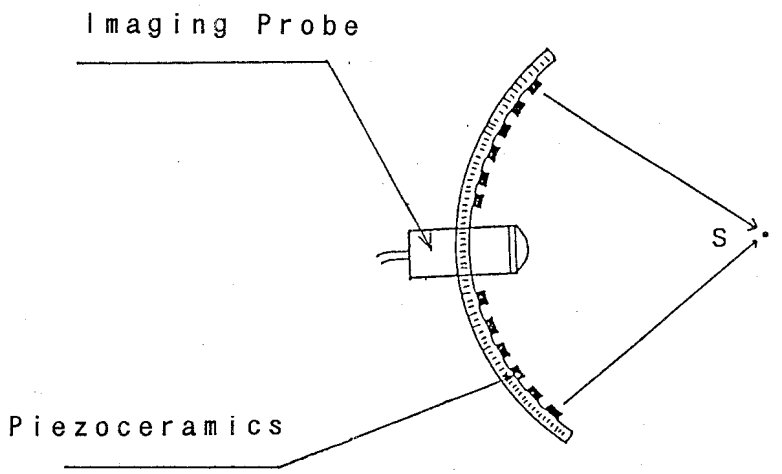

Fig. 5 Applicator equipped with largè-type piezoceramics.

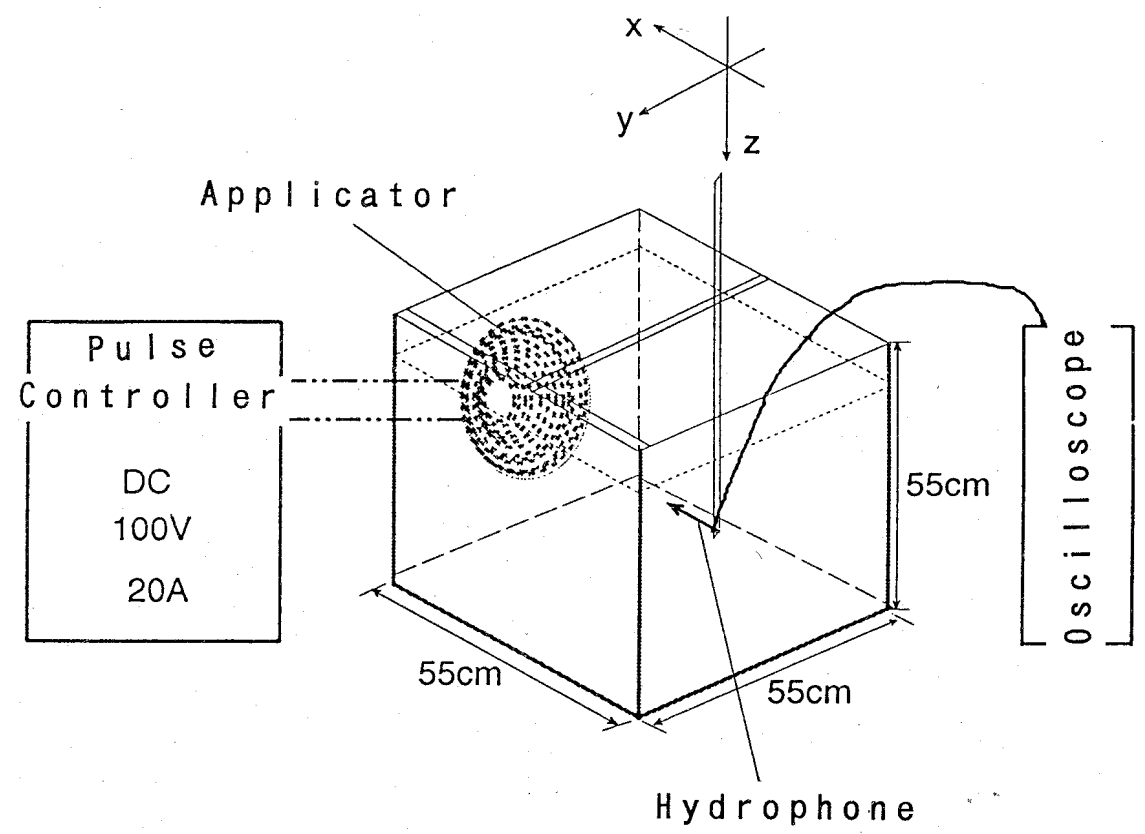

Fig. 4 Experimental equipment for ESWL.

$\mathrm{F}(\mathrm{t})$ に位相差相当分を取り込んだ次式

$$
F_{1}(t)=\frac{1}{2}\left[1-\cos \left\{\frac{\omega}{4}\left(t-T_{D E L}\right)\right\}\right] \sin \left(t-T_{D E L}\right), 0 \leqq t \leqq 4 T
$$

$=0, \mathrm{t}<0$ or $\mathrm{t}>4 \mathrm{~T}$

の $\mathrm{F}_{1}(\mathrm{t})$ を $y$ 軸上の $\mathrm{ab}$ 及び $\mathrm{cd}$ 上に与えることにする。 ただし，Cは領域 2 亿扔るる音速であり

$$
\begin{aligned}
& \mathrm{T}_{\mathrm{DEL}}=\frac{1}{C}\left(\overline{\mathrm{Q}_{\mathrm{L}} \mathrm{S}}-\overline{\mathrm{Q}_{y} \mathrm{~S}}\right) \\
& \overline{\mathrm{Q}_{y} \mathrm{~S}} \sqrt{\left(\mathrm{y}-\frac{\mathrm{y}_{\mathrm{m}}}{2}\right)^{2}+\mathrm{x}_{s}^{2}}
\end{aligned}
$$

$$
\text { である。 }
$$

\section{4 超音波の伝搬損失}

超音波は媒質内を伝搬するとその強さは隇衰する。

(2)式はこの損失項を考慮すると次式にように近似される。 $-\frac{\partial \mathrm{P}}{\partial \mathrm{t}}=\mathrm{K} \nabla \cdot \mathbf{V}+\mathrm{KSP}$

(18)式を差分化し， $\mathrm{P}^{\mathrm{n}+1}$ が左辺にくる式を求めると
$\mathrm{P}^{\mathrm{n}+1}(\mathrm{i}, 1)=\frac{1-\frac{\mathrm{KS}}{2} \delta \mathrm{t}}{1+\frac{\mathrm{KS}}{2} \delta \mathrm{t}} \mathrm{P}^{\mathrm{n}}(\mathrm{i}, 1)-\frac{\mathrm{K} \delta \mathrm{t}}{1+\frac{\mathrm{KS}}{2} \delta \mathrm{t}}\left[\frac{1}{\delta x}\left\{\mathrm{~V}_{x}^{\mathrm{n}+\frac{1}{2}}\left(\mathrm{i}+\frac{1}{2}\right.\right.\right.$,

1) $\left.\left.\left.\left.-\mathrm{V}_{x}^{\mathrm{n}+\frac{1}{2}}\left(\mathrm{i}-\frac{1}{2}, 1\right)\right\}+\mathrm{V}_{y}^{\mathrm{n}+\frac{1}{2}}\left(\mathrm{i}, 1+\frac{1}{2}\right)-\mathrm{V}_{y}^{\mathrm{n}+\frac{1}{2}}(\mathrm{i}, 1-) \frac{1}{2}\right)\right\}\right]$ (19) となる. (19)式の KS の值は，人体媒質中で $0.5 \sim 1 \mathrm{MHz}$ のとき 12 $\mathrm{cm}$ で約 0.5 倍に減衰する ${ }^{11}$ ように選ぶと

$$
\mathrm{KS}=11.55 \mathrm{C} \quad\left[\frac{1}{\mathrm{sec}}\right]
$$
となる。

\section{3. 実験}

\section{1 実験 装置}

Fig.4 のような一辺が55 $\mathrm{cm}$ の立方体の水槽に水道水を充媜し, 水槽の側面に超音波パルス発生源のアプリケー夕を取り付けたも のを実験装置として用いる。このアプリケー夕は環状球面上に大 型ピエゾ素子群を周密に張り付けたものであり, 外形 $30 \mathrm{~cm}$, 曲率 半径 $18 \mathrm{~cm}$ で, 中心部に超音波診断装置のイメージングプローブ 
を取り付ける開口部（直径 $6 \mathrm{~cm}$ ) が設けられている，アプリケー 夕の概略を Fig. 5 亿示す。超音波波形の検出は針状の音压センサ ーPVDF ハイドロフォン (IMOTEC 社製：GmbH) で行う。こ のハイドロフォンの感度は $U_{\text {probe }}^{*}=Q_{\text {probe }}^{*} / C_{\text {sum }}$ で示され, $U_{\text {probe }}^{*}$ の単位はVolt/bar, Q Q probe は0.182 pC/bar, C る.

水槽に対して $x, y, z$ 軸をFig. 4 の上うに設定したとき，八イ ドロフォンは $x, y, z の 3$ 方向に自由に動くようになっている. ハイドロフォンで検出した波形信号は同軸線路でオシロスコーナ に導かれ，振動子から発射されるパルス波形がディスプレイ上に 写し出される。

ここで,オシロスコープの性能について簡単に述べると, 型式 はVP-5730A，入力感度は $2 \mathrm{mV} / \mathrm{DIV} \sim 5 \mathrm{~V} / \mathrm{DIV} 1$ ，2，5 ステ ップ, 11 レンジ, 確度は土3\%, 带域楅は $5 \mathrm{mV} \sim 0.2 \mathrm{~V} / \mathrm{DIV} て ゙ \mathrm{DC}$ 〜 $50 \mathrm{MHz}, 2 \mathrm{mV} / \mathrm{DIV}$ で DC〜25 $\mathrm{MHz}$ である.

\section{2 波形変化}

振動子は球面上に配置されているので球の中心に向かって超音 波パルスが集束していくように后搬していく，そこで球の中心を 焦点 (S) と呼ぶことにする。この焦点を中心として水槽内でハイ ドロフォンを移動させ，いろいろな点で波形を測定する。焦点を 中心として振動子に垂直方向 ( $x$ 軸方向) に-20 mm〜 + $20 \mathrm{~mm}$ の範囲でハイドロフォンを移動（Fig.6のIJ上）させたときの音

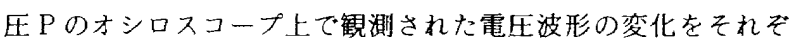
れ Fig. 7 の(a)，(b)，(c)，(d)，(e)，(f)に示す.

\section{3 最大值の分布}

八イドロフォンを焦点の位置から振動子の垂直方向 ( $x$ 軸方向) に $x=-10,0,+10 \mathrm{~mm} の 3$ 点を選び, 水平方向 ( $y$ 軸方向)に 焦点を中心として $\pm 35 \mathrm{~mm}$ の範囲を0.5 mm 間隔で移動（Fig. 6 の $\mathrm{KL}, \mathrm{K}^{\prime} \mathrm{L}, \mathrm{K} \mathrm{K}^{\prime \prime} \mathrm{L}$ ”上)させ, 各点でのパルス波形を観測し最大 值を湖定することによって，超音波パルスの集束状況及びその质 乘状況を観測した， $x=-10 \mathrm{~mm}, 0,+10 \mathrm{~mm}$ における各点での 最大值の $y$ 方向分布を Fig. 8 のbに示寸。各図の横軸（ $y$ 軸）の 单位は $[\mathrm{mm}]$, 綎軸は音死 $\mathrm{P}$ に比例与る電圧值 $\mathrm{P}[\mathrm{mV}]$ である が，記号 $\mathrm{P}$ をそのまま用いている。また，横軸の矢印で示した37 $\mathrm{nm}$ の位置は焦点の $x$ 座標である。

\section{4 損失のある媒質中の伝搬}

実際には超音波が媒質中を伝搬すると損失を生じる。この損失 を検討するため，振動子と焦点との間に肝莶と隇衰率が等価なつ アントムを設㯰して、ファントムのない場合とある場合でパルス 波形にどのような変化があるか観察した (Fig. 6 の EFGH に相当 する位置にこのファントムを設定した）、今回使用したファントム は寒天, グラファイト，ノルマルプロパノール(アルコール； $C_{3}$ $\left.\mathrm{H}_{7} \mathrm{OH}\right)$ を成分としこれをウレタンゴムで覆ったものである。この ファントムの厚さは $40 \mathrm{~mm}$ で, 0.5〜 $1 \mathrm{MHz}$ の超音波においての 減衰率は 13.0 neper $/ \mathrm{m}$ ，音速は $1600.0 \mathrm{~m} / \mathrm{sec}$ である. Fig. 9 にフ アントムがある場合（損失あり）とない場合（損失なし）の焦点 付近における波形を示す。なお，損失のある場合は実線で示し， ない場合は点線で示している。

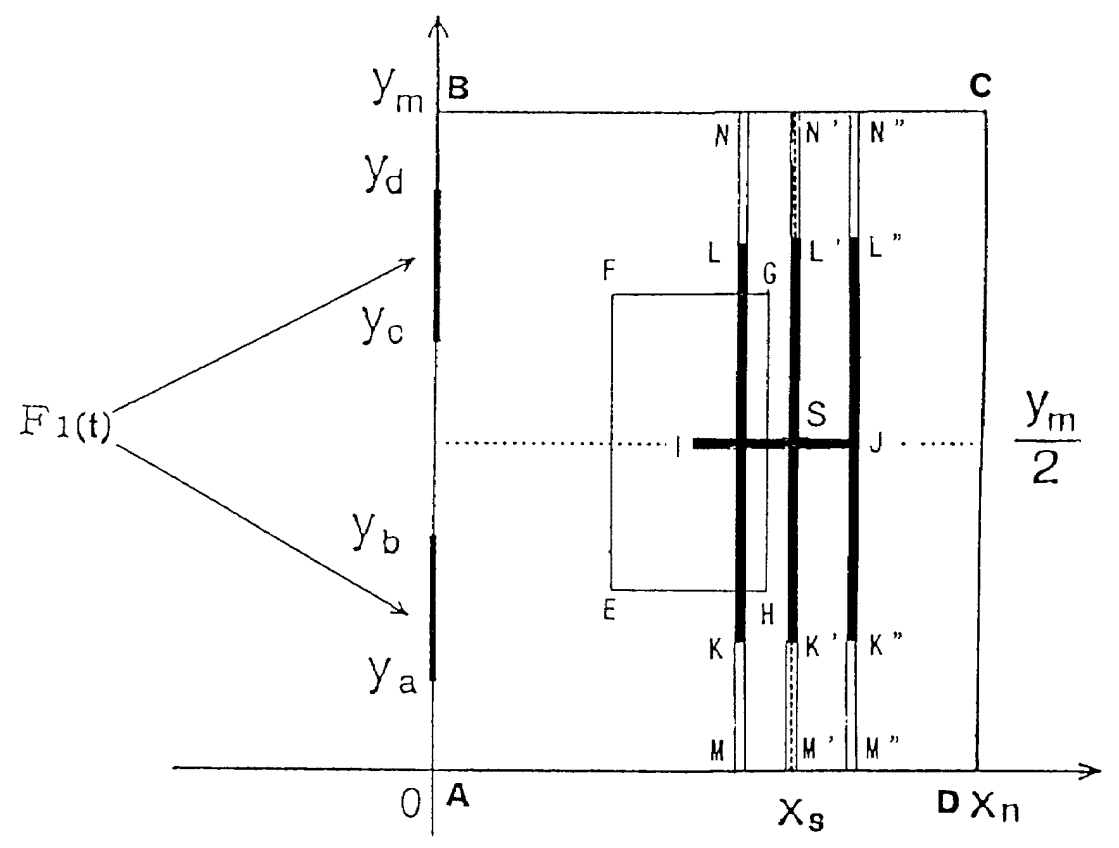

Fig. 6 Model of experiment, calculation and absorptive medium and those areas. 


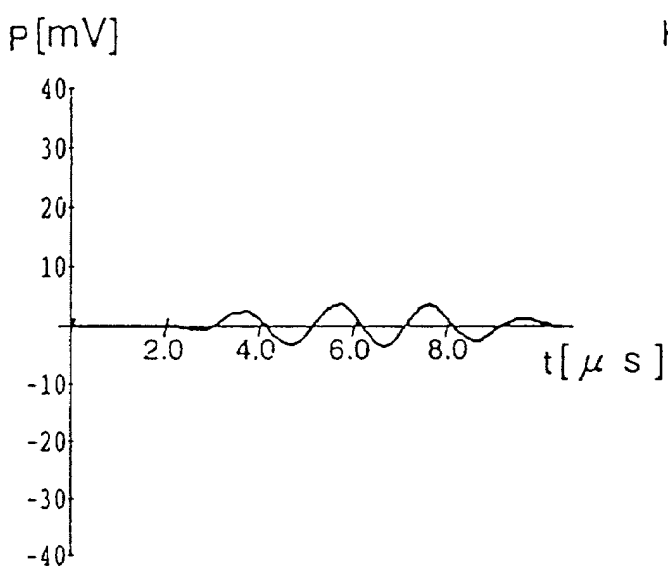

(a ) $x=-20 \mathrm{~mm}$

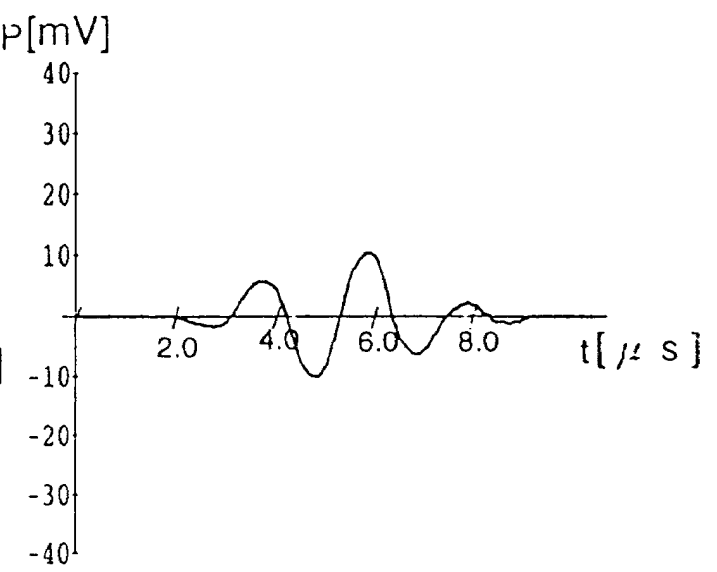

(d) $x=+10 \mathrm{~mm}$

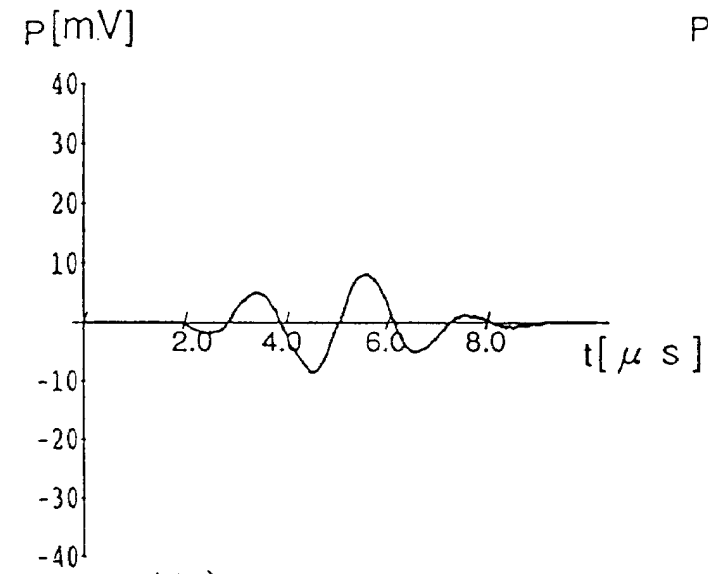

$\mathrm{P}[\mathrm{mV}]$

(b) $x=-10 \mathrm{~mm}$

$\mathrm{P}[\mathrm{mV}]$
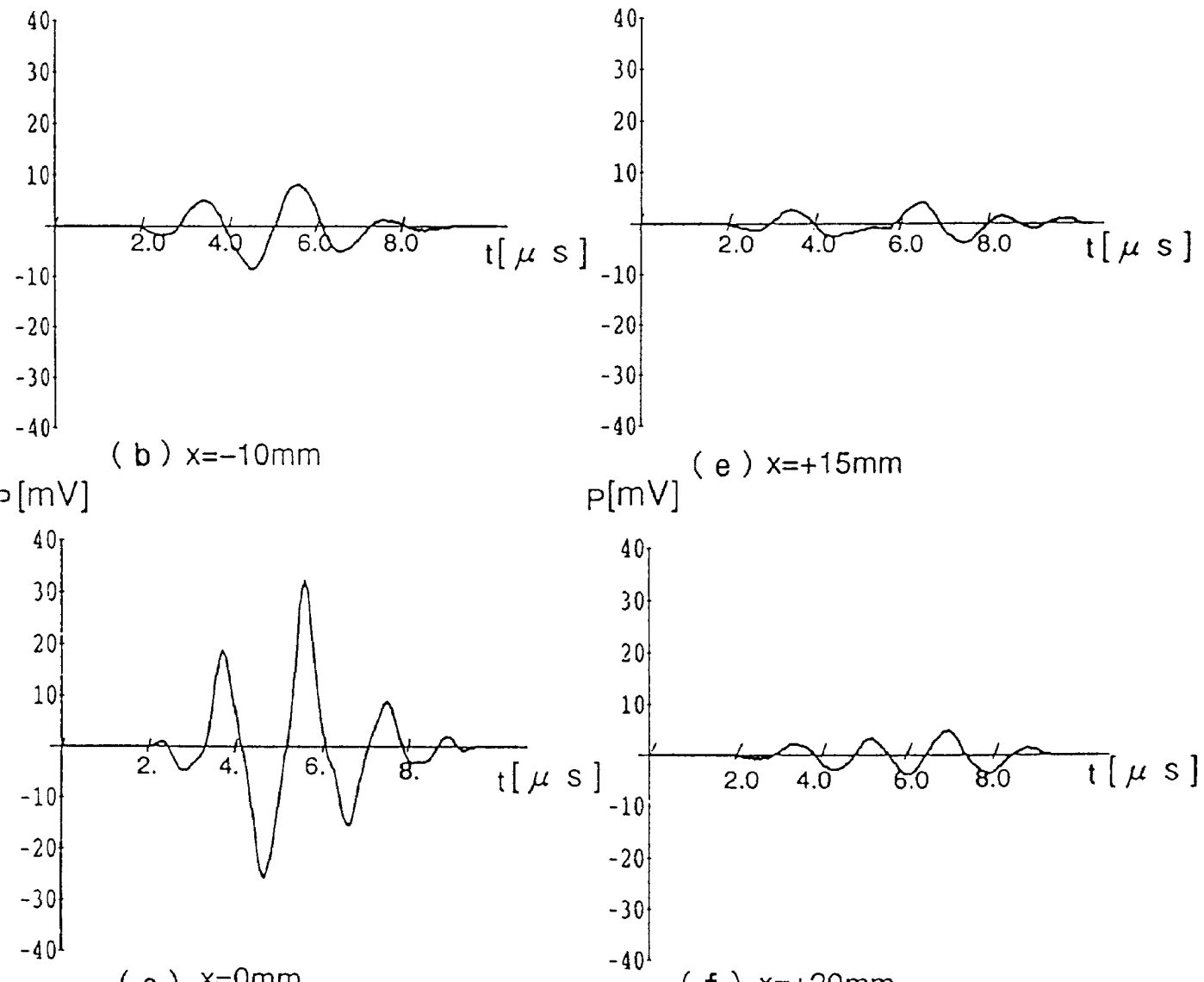

$P[\mathrm{mV}](\mathrm{e}) \mathrm{x}=+15 \mathrm{~mm}$

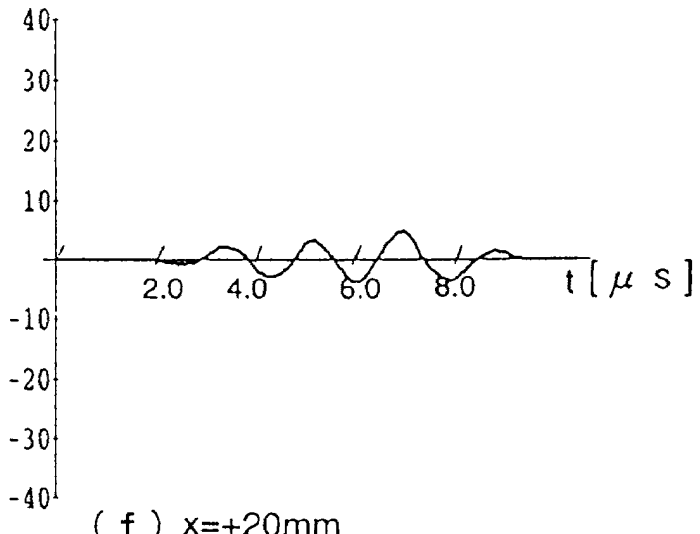

(f) $x=+20 \mathrm{~mm}$ 

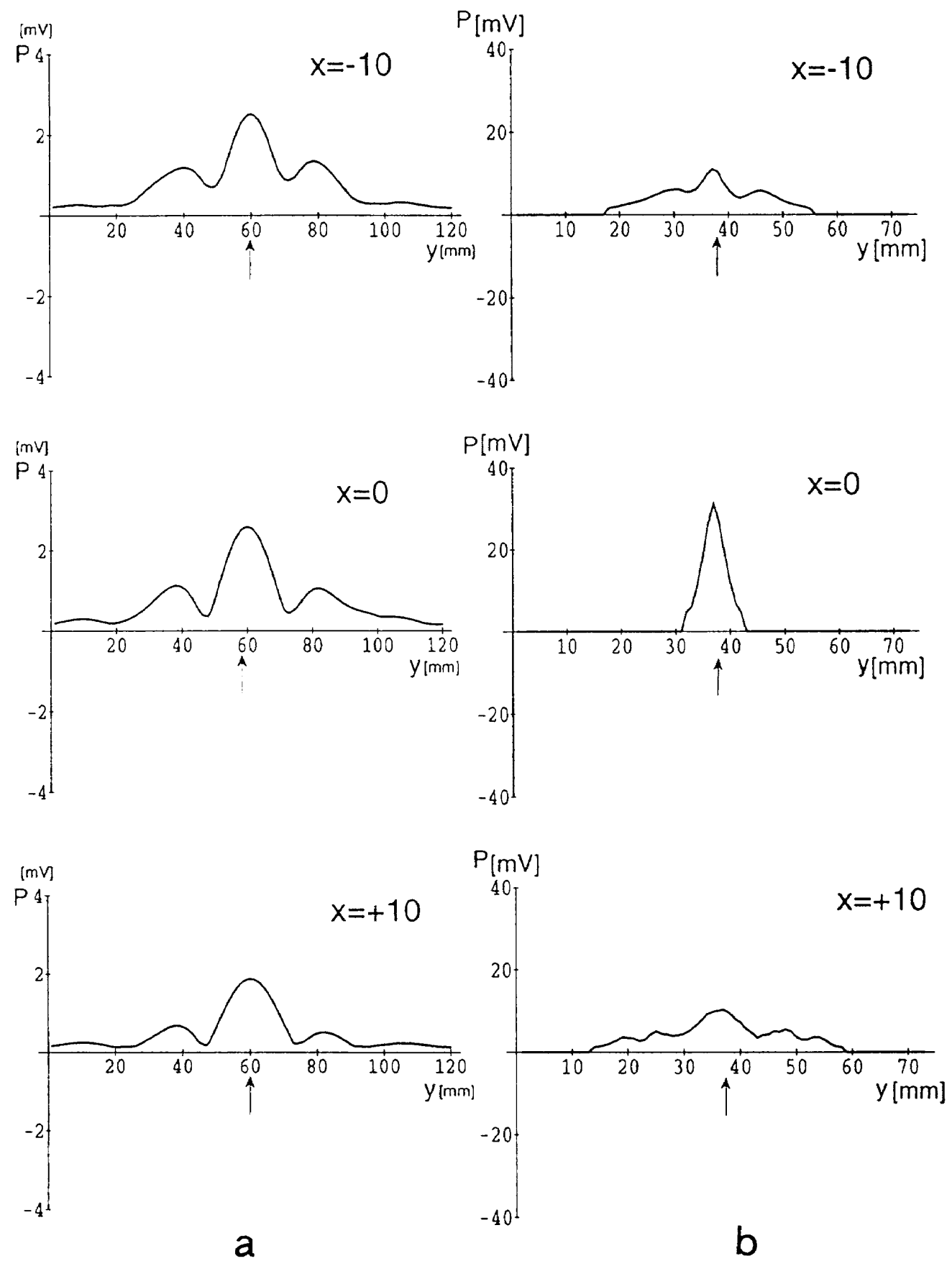

Fig. 8 Distribution of peak of sound pressure.

a Distribution of the sound pressure peak using a calculation

b Distribution of the sound pressure peak carried out expere mentally 


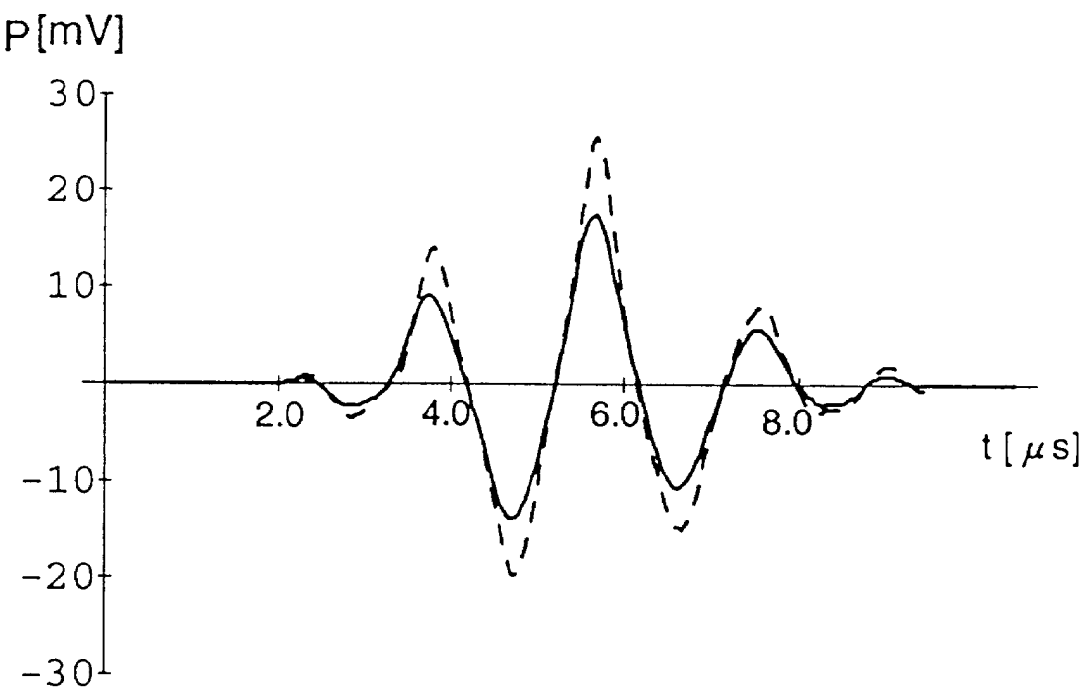

Lossy Case--- Lossless case

Fig.9 Waveform of sound pressure of the ultrasonic pulses near the focus by experiment (for lossless case and lossy case)

\section{4. 数値計算及び検討}

4.1 波形变化

ここでは，Fig.6のように数值計算領域を $0<x<x_{\mathrm{n}}, 0<y<y_{\mathrm{m}}$

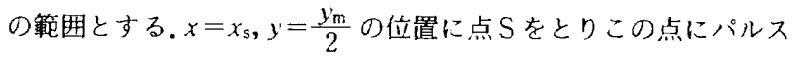
を集束させることを目的とする， $x_{\mathrm{n}}, y_{\mathrm{m}}$ はそれぞれ $x$ 軸，y軸方 向の計算領域の長さ， $\delta x ， \delta y$ はそれぞれ $x$ 軸， $y$ 軸方向のメッシ 工間隔，T は励振関数の 1 周期，C は音速， $\rho$ は媒質の密度とし， 実際の計算ではこれらの值は次のように選んでいる。

$$
\begin{aligned}
& x_{\mathrm{n}} \times y_{\mathrm{m}}=90 \mathrm{~mm} \times 120 \mathrm{~mm} \\
& x_{\mathrm{s}}=60 \mathrm{~mm} \\
& \text { メッシュ数 : } x_{\mathrm{n}} \text { を } 180 \text { 等分, } y_{\mathrm{m}} \text { を } 240 \text { 等分 } \\
& \text { メッシュ間隔 }: \delta x=\frac{90}{180}=0.5 \mathrm{~mm} \\
& \qquad \quad \delta y=\frac{120}{240}=0.5 \mathrm{~mm} \\
& \mathrm{~T}=6 \mu \mathrm{s} \quad \delta \mathrm{t}=\frac{\mathrm{T}}{40} \\
& \mathrm{C}=1,540 \mathrm{~m} / \mathrm{s} \quad(\text { 一様生体組纎内で })^{12)} \\
& \rho=1.0 \mathrm{~g} / \mathrm{cm}^{3}
\end{aligned}
$$

これらのことを考虑したうえで, $y_{\mathrm{B}} y_{\mathrm{b}}$ 及び $y_{\mathrm{c}} y_{\mathrm{d}}$ 間で与える励振関 数 $\mathrm{F}_{1}(\mathrm{t})$ 沬(15)式とした場合について超音波パルスの集束状況およ び伝搬状況をFig. 10, Fig.11に示す. Fig.10, Fig.11の（a-1） 〜(a-4) は, $\frac{y_{m}}{2}$, すなわちメッシュ番号 l=121の線上における 時間変化波形である。 $x$ 軸の単位を $[\mathrm{mm}], y$ 軸の単位を $[\mathrm{mV}]$ としており，焦点を矢印で示している. $(\mathrm{b}-1) \sim(b-4)$ はその時の 超音波パルスの音圧分布を濃淡表示したものであり, $x$ 軸, $y$ 軸と も [mm] として，焦点を+印で示している。

\section{2 最大値の分布}

ここでは, Fig. 6 で示すような計算領域 $0<x<x_{\mathrm{n}}, 0<y<y_{\mathrm{m}}$ の なかの，焦点 $\mathrm{S}$ を含む四角形領域 $\mathrm{ABCD}$ 内でのパルス波形の最 大值を計算により求め，その $y$ 軸方向分布を計算した結果を示 す。焦点 S から $x$ 軸方向に $-10 \mathrm{~mm}, 0,+10 \mathrm{~mm}$ の 3 点をとり, $y$ 軸方向に岋焦点 S から $260 \mathrm{~mm}$ の範囲で $0.5 \mathrm{~mm}$ の間隔（Fig. 6 の MN, M'N"，M"N"上)にとって各点のパルス波形の最大值 を表示した結果をFig. 8 のにに示す.

\section{3 損失のある媒留中の伝䑪}

ここでは，Fig. 6 に示すような数值計算領域中の，四角形領域 $\mathrm{EFGH}$ 内に2.4で述へた損失項の式を設定し，損失のない場合と ある場合のパルス分布を数值計算により求める. EFGH の領域は 焦点加ら $x$ 軸方向に $-5 \mathrm{~mm}$ を基準にー400 mm (ファントムと同 じ厚さとした,$y$ 軸方向に $y$ 軸中心 $\left(y_{\mathrm{m}} / 2\right) よ り \pm 50 \mathrm{~mm}$ の範囲 とした。パルス波形分布の結果を Fig. 12 に示す。なお，損失のあ る場合は実線で示し，ない場合は点線で示している。

\section{4 計算結果と実験結果の比較検討}

4.4 .1 波形変化

まず，数値計算結果で得られた Fig. 10，Fig.11について検討す る.励振された後の超音波パルスが，焦点の近くまでくるとより 強くなっているのがこれらの図からわかる。これは焦点への集束 効果によるものである. また, Fig. 10, Fig.11の(b-1)〜 (b-4)に おける瀁淡表示を見ると，より一層焦点に向かって超音波パルス が集束してゅく状態を観察することができ，焦点を過ぎると㹡散 していることがわかる，次に，焦点付近での超音波パルスの波形 を数值計算で得た Fig. 11(a-3) と実験結果の Fig.7 (c)とで比較す ると, Fig. 11(a-3)の振幅は Fig. 7(c)の波形の約 1/10になってい るが波形は酷似していることがわかる。これは実験測定がうまく いった事とともに，計算で仮定した入射パルス波形が実際の波形 とよく似たものであった事を意味している，数值計算が 2 次元問 

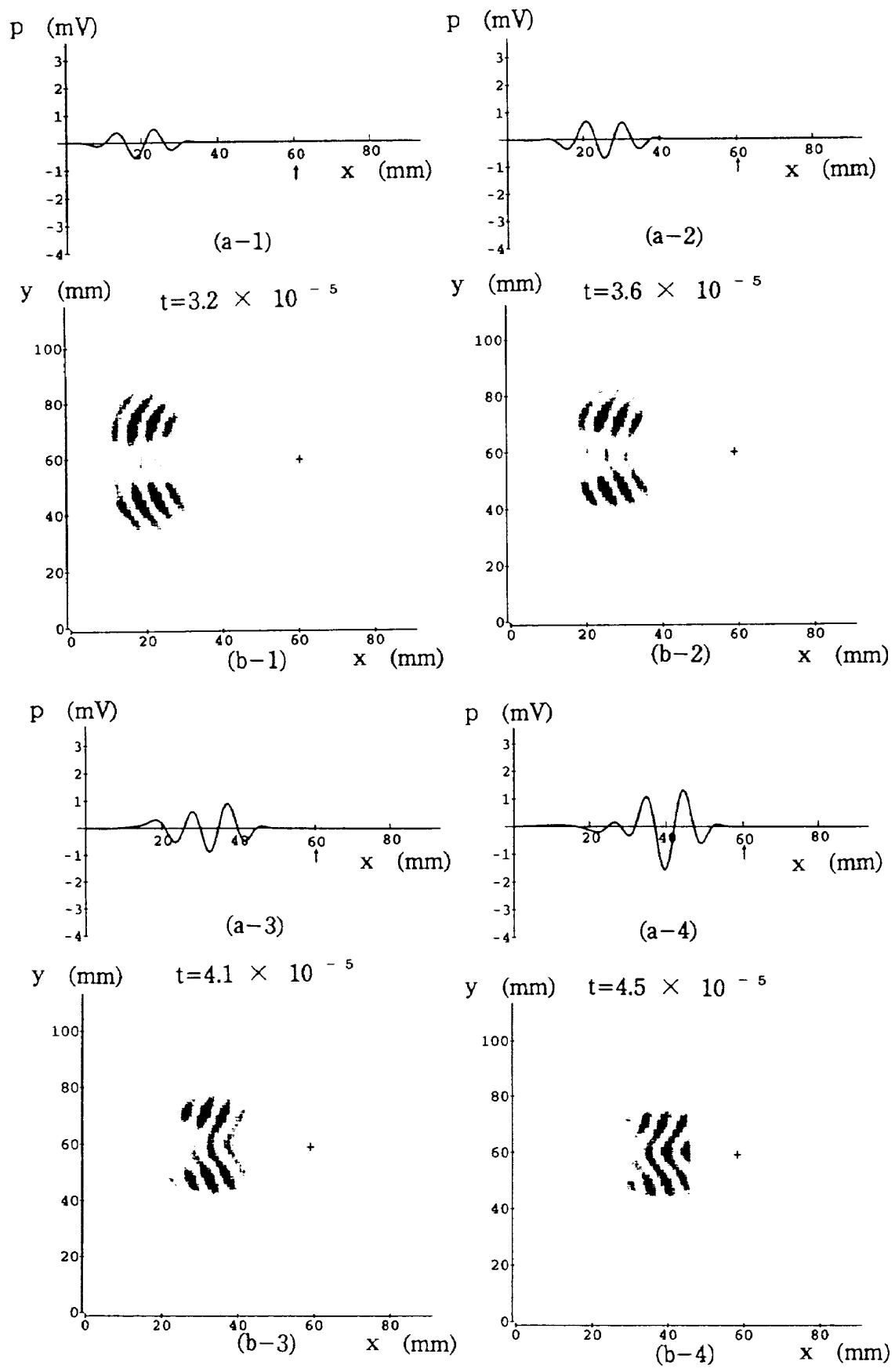

Fig. 10 Waveform of propagation of pulses $(a-1),(a-2),(a-3),(a-4)$ and light-and-shade representation $(b-1),(b-2),(b-3),(b-4)$ of the sound pressure distribution for each time.

題であるのに対し実験は 3 次元構造であることを考えると非常に 興味深い結果である。

\section{4 .2 最大値の分布}

Fig. 8 の aで数值計算の場合は滑らかな分布となっているが, 実際行った波形観測では八イドロフォン，オシロスコープ等の性 能限界のために滑らかな分布には必ずしもならないことを考慮し たうえで数値計算結果と実験結果をそれぞれ比較検討する。数值
計算により求めた最大値の分布では, 焦点より前方 $(x=-10$ $\mathrm{mm}$ ) では横軸の $60 \mathrm{~mm}$ の位置 (焦点 $\mathrm{S} の x$ 座標) が最大ピーク 場所で，その左右にもピークが現れている。実験結果の分布でも 同様なことが言え，最大ピーク場所を中心として左右にもピーク が現れている．実験で測定できる最小值に限界があることを考え ると、この両者がかなり定性的に一致していると考えてよいとも 言える，焦点においては，数值計算結果は焦点より前方の分布と 

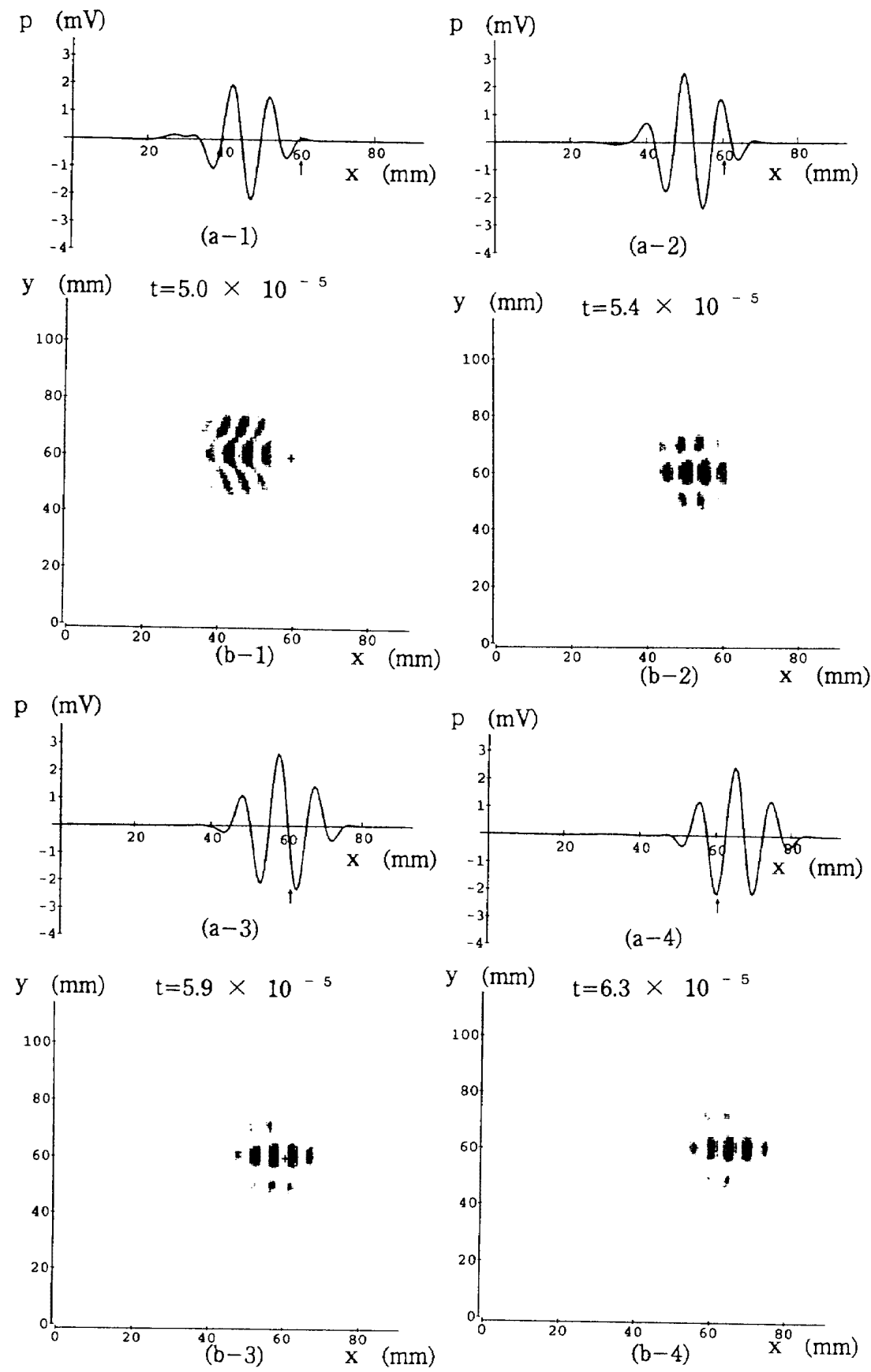

Fig. 11 Waveform of propagation of pulses $(a-1),(a-2),(a-3),(a-4)$ and light-and-shade representation $(b-1),(b-2),(b-3),(b-4)$ of the sound pressure distribution for each time.

同様に3つのピーク場所が現れているが，実験結果のほうは数值

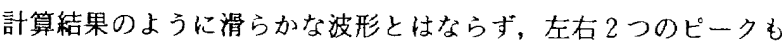
ないものとなった．焦点から遠ざかると $(x=+10 \mathrm{~mm})$ 最大ピー ク，その左右ピークの場所いずれも娍衰が激しくなっている。こ れは入射された超音波パルスの㹡散する性質が焦点より後方で目 立って現れることが原因であると思われる。

\section{4 .3 損失のある媒質中の伝搬}

焦点付近での超音波パルスの損失がある時とない時の数値計算 で得たFig. 12 と実験結果の Fig. 9 とを比較する。実線が損失が ある時で点線がない時であるが，損失の程度がほほ同じ位で， 25〜30\%である。このことは肝媙と価な吸収率をもつファント ムと計算に用いた吸収の度合いが同じであることを示している。 


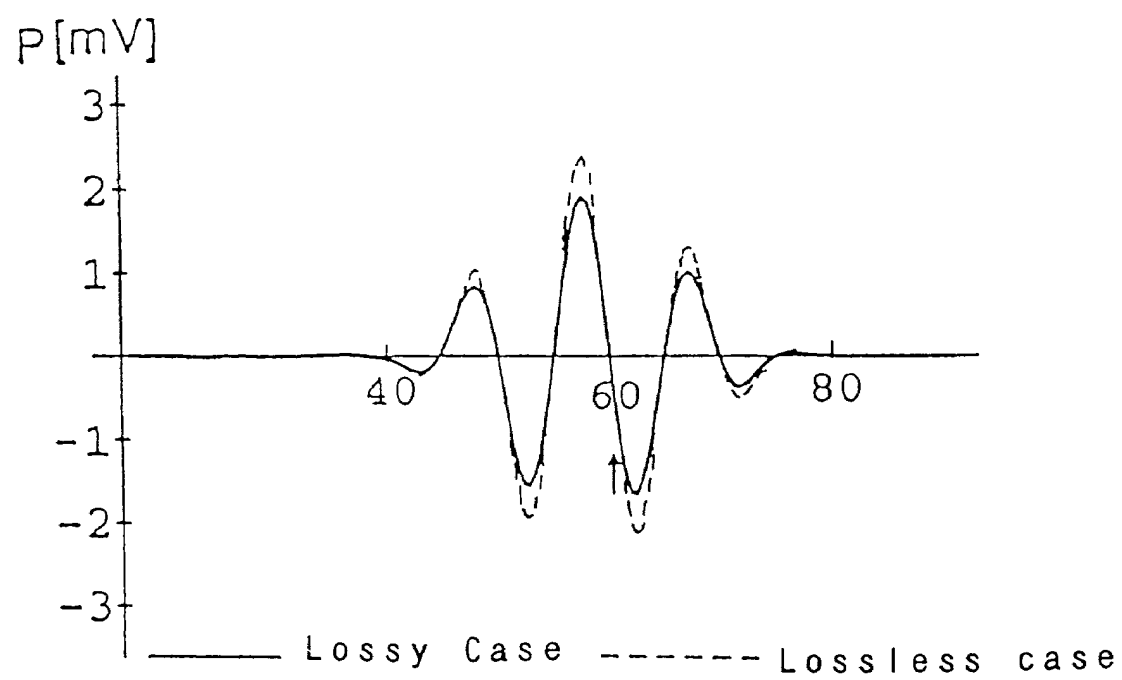

Fig. 12 Waseform of sound pressure of the ultrasonic pulses near the focus carried out using a calculation (for lossless case and lossy case).

\section{5. 結 論}

本研究は，新しくエ夫した時間領域数值計算法を用いて衝撃波 結不破砕装置から発射されたエコートリガ超音波バルスが水領域 内芯自搬しなが焦点へ集束していく状況を数值シミュレーショ

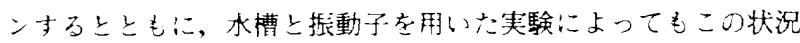

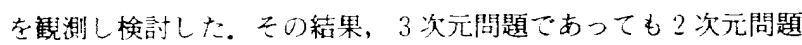
レしての計算が可能であり，定性的にはかなり正確に再現できる。 損失がある場台もモデルを压夫する上数値計算上実験結果を比較 的よく一致きせることができること，などが解った。

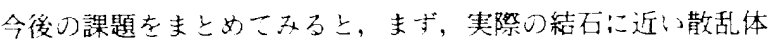
在焦点に置いて実験するこょ，また，水槽の水索人体に近い成分 の損失性媒質にし，温度も体温くらいにして観察するなどがある。 オシロスコーブをより精度の高いもりにすることも今後つ課題で ある。

本文の方法は，衝揧波結石破研装置のエコートリガに限らず， 幅层く超音波バルスの生体組織内に沽引る层般, 吸収, 反射の解 折に用いる事ができる。

医㞠界に扔ける最近の超音波を利用しなモダりテ亿の進歩は目

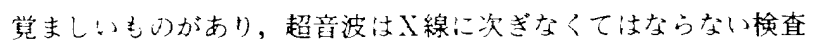
手段となっている，その最大理由仿手軽な装置であるこ々上，人 体には無害であり，かつ非侵襲的な検査が可能なことである。し かし，二机らの超音波技術にもまだまだ種々の末解沈な問題が残 っている，筆者等は本研究が発展して超等波に関する諸問題が解 決され，更江超音波医療技術が発展与るこ上在期待する。

\section{参考文献}

1) Okazaki K. Iwama $\mathrm{X}$. Nomura S: Process of Change from Litrasonic Wave to Shock Wave Lithotrips: L'sing Piezoceramic Transducer. Jpn. J. Appl. Physs., 30-1, 216218. (1991).

2) Kandel LB. Harrison LH. Mccullough DL: State of the Art ESWL. Futura Pub. Co, N.Y. (1987).

3) Okazaki K. Aida S. Iwama N. et al.; Fundamental Study in Extracorporeal Shock Wave Lithotripsy Lsing Pi- ezoceramics, Jpn. J. Appl. Phys., Vol. 28., Suppl. 28-1, 143 -145, (1987).

4）岩間信行, 岡䗁 清, 野村 哲, 山中昭一, 他：体外衝拲波 結石破确における誤照射防止機能の有用性の検討, JSUM Proceedings, 191-192, (Oct. 1990).

5）岡崎 清，岩間信行，野村 哲，他：体外衝撃波結石破砕に よる䛊照射防止機構の有用性, 第11回超音波エレクトロニク スの基礎と応用に関するシンポジュウム講演予稿集, 京都, 120-121, (Nov. 1990).

6) Ioritani N. Orikawa S, Kuwahara M: The Correct Targeting Rate in ESWL Treatment Measured by An AntiMiss-Shot Control Device. Jpn. J. Endourology and ESWL., 3, 2, 179-186. (1990).

7) Yee KS: Numerical Solution of Boundary Value Problems Involving Maxwell's Equations in Isotropic Media. IEEE Trans. on Antennas \& Prorag., Vol AP-14, No.3, 302-307. (May. 1966).

8) Taflove A, Umashankar KR: The Finite -Difference Time- Domain Method for numerical modeling of electromagnetic wave interactions with arbirary structures, in M.A. Morgan, ed. Finite Element and Finite Difference Methods in Electromagnetic Scattering, Chap. 8, Elsevier, (1990).

9）柏達也, 秋田博正, 霜田英麿, 他: ベクトル量を用いた音 響時間領域差分法とその散乱解析への応用信学論, J74-A， 1113-1115，(1991).

10）千葉 修, 柏 達也, 霜田英麿, 他 : リープフロッグアルゴ リズムに基づく時間依存差分法による3次元音場解析 日本 音響学会誌，49，8，551-562，(1993).

11) Robert BR: Litrasonic Heating Techniques, NATO. ASI. Ser. E., 127, 390-401, (1987).

12) Kondo M. Takamizawa O. Hirama M, et al.; An Evaluation of an In Vivo Local Sound Speed Estimation Technique by the Cross Beam Method, Ultrasound in Med. \& Biol.. 16, (1), 65-i2, (1990). 